\title{
Review \\ On the Importance of Pnictogen and Chalcogen Bonding Interactions in Supramolecular Catalysis
}

\author{
Antonio Frontera (D) and Antonio Bauza * (D) \\ Departament de Química, Universitat de les Illes Balears, Crta. de Valldemossa km 7.5, \\ 07122 Palma de Mallorca, Baleares, Spain; toni.frontera@uib.es \\ * Correspondence: antonio.bauza@uib.es
}

check for updates

Citation: Frontera, A.; Bauza, A. On the Importance of Pnictogen and Chalcogen Bonding Interactions in Supramolecular Catalysis. Int. J. Mol. Sci. 2021, 22, 12550. https:// doi.org/10.3390/ijms222212550

Academic Editor:

Salah-Eddine Stiriba

Received: 4 November 2021

Accepted: 19 November 2021

Published: 21 November 2021

Publisher's Note: MDPI stays neutral with regard to jurisdictional claims in published maps and institutional affiliations.

Copyright: (c) 2021 by the authors. Licensee MDPI, Basel, Switzerland. This article is an open access article distributed under the terms and conditions of the Creative Commons Attribution (CC BY) license (https:// creativecommons.org/licenses/by/ $4.0 /)$.
Abstract: In this review, several examples of the application of pnictogen (Pn) (group 15) and chalcogen (Ch) bonding (group 16) interactions in organocatalytic processes are gathered, backed up with Molecular Electrostatic Potential surfaces of model systems. Despite the fact that the use of catalysts based on pnictogen and chalcogen bonding interactions is taking its first steps, it should be considered and used by the scientific community as a novel, promising tool in the field of organocatalysis.

Keywords: $\sigma$-hole interactions; pnictogen bonding; chalcogen bonding; supramolecular chemistry; catalysis

\section{Introduction}

Elements belonging to groups 13-18 and covalently bound to electron withdrawing groups (EWG) possess an inherent ability to interact with Lewis bases, such as lone pair donors, $\pi$-systems and anions [1-13]. Since the first use of the electropositive site to describe the hydrogen bonding (HB) interaction, it became commonplace to use the name of the group to which the electrophilic atom belongs to name noncovalent interactions (NCI) involving electrophilic and nucleophilic sites [14,15]. In this context, the International Union of Pure and Applied Chemistry (IUPAC) has already recommended the terms halogen bond $(\mathrm{HaB})$ [16] and chalcogen bond (ChB) [17] for naming the NCIs involving atoms from groups 17 and 16, respectively. Furthermore, aerogen or noble gas bonding (NgB, group 18) [12], pnictogen bonding (PnB, group 15), [18,19] tetrel bonding ( $\mathrm{TtB}$, group 14) [20], and triel bonding ( $\mathrm{TrB}$, group 13) [7] have been used for main group elements not yet recommended by the IUPAC. In addition, matere bonding (MaB, group 7) [21], osme bonding (OmB, group 8) [22], spodium bonding ( $\mathrm{SpB}$, group 12) [23] and regium or coinage bonding ( $\mathrm{CiB}$, group 11$)[24]$, have been recently used to refer to NCIs where elements from groups 7, 8, 11 and 12 act as Lewis acids, and to differentiate them from classical coordination bonds [24-27]. Many studies have reported the feasibility of $\sigma$-hole interactions as an alternative to HB interactions in a broad spectrum of fields, such as host-guest chemistry, catalysis, supramolecular chemistry, membrane transport, crystal engineering, etc., [28-35]. A great deal of review articles and book chapters are available in the literature describing the basic features and potential applications of this group of NCIs [28-45]. Moreover, several studies have been devoted to the comparison of $\sigma$-hole interactions to the HB in terms of energetic and geometric features [46-51].

The attractive interaction (EWG-X ‥A) between a p-block element (Lewis acid, X) and a $\sigma$-hole acceptor (A, Lewis base, anion or $\pi$-system) is supported by the sum of different contributions (see Figure 1 for a Molecular Electrostatic Potential (MEP) surface of a prototypical $\mathrm{CF}_{3} \mathrm{Br} \cdots \mathrm{NH}_{3}$ complex). These correspond to electrostatics, charge transfer, orbital mixing, polarization and dispersion forces [52,53]. Firstly, electrostatics is understood as the attraction between the electron-rich region (belonging to the electron donor $(\mathrm{A})$ ) and a region of diminished electrostatic potential located at the prolongation of the EWG-X bond, known as the $\sigma$-hole (which belongs to the electron acceptor). Secondly, dispersion 
and polarization terms are also important contributors to those NCIs involving the heavier elements of the groups, which are easily polarized [45,54-60]. Lastly, the orbital term is rationalized as the global stabilization of the complex owing to the electron donation from the electron-rich atom or group of atoms (e.g., $\mathrm{LP}(\mathrm{A})$ or $\pi(\mathrm{A}))$ to an antibonding EWG-X orbital $\left(\sigma^{*}(\mathrm{EWG}-\mathrm{Y})\right.$. Since the polarizability of the atoms increases when descending the groups of the periodic table, the electropositive region of the $\sigma$-hole increases if the EWG- $X$ bond is more polarized, thus resulting in a reinforcement of the NCI. In addition, increasing the electron-withdrawing ability of EWG is another way to polarize the EWG-X bond. Thus, the combination of heavy elements and strong EWGs increases the positive potential and size the $\sigma$-hole, which results in the strengthening of the NCI. This has led to an increase of the number of investigations [61-74] involving elements of groups 14-18, which has paved the way of new lines of research [14,15].

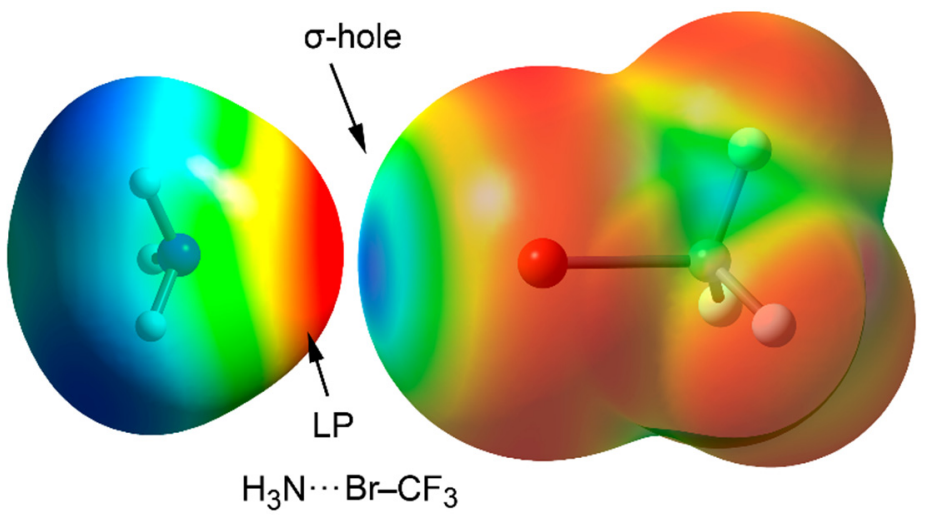

Figure 1. MEP surface of an $\sigma$-hole complex between $\mathrm{NH}_{3}$ and $\mathrm{BrCF}_{3}$ molecules acting as electron donor and acceptor moieties, respectively. Electropositive regions are represented in blue and electronegative in red.

\section{Results and Discussion}

\subsection{Pnictogen Bonding}

A great deal of studies dealing with PnBs are already available in the literature [43,44,75-85]. However, those presenting experimental evidence of the interaction are scarce [86-89].

Table 1 gathers the atomic polarizability values $(\alpha)$ and van der Waals radii of the pnictogen elements from period two to five. The atomic $\alpha$ value increases from 5.3 a.u. in $\mathrm{N}$ to 30.8 a.u. in $\mathrm{Sb}$. As noted, the difference in $\alpha$ between $\mathrm{N}$ and $\mathrm{P}$ is substantial ( $3 \mathrm{x})$, and small between $\mathrm{P}$ and As. Lastly, the difference is again relevant between As and $\mathrm{Sb}$. In Table 1, the MEP values at the $\sigma$-holes of the fluoride derivatives of the four Pn elements are also gathered, while Figure 2 includes the MEP surface for $\mathrm{SbF}_{3}$. As noted, the MEP values at the $\sigma$-hole become more positive when descending in the group, similarly to the well-characterized halogen bond interaction.

Table 1. Atomic polarizabilities ( $\alpha$, a.u.) of pnictogen (Pn) elements, van der Waals radii $\left(\mathrm{R}_{\mathrm{vdW}}, \AA\right)$ and $\sigma$-hole MEP value (MEP, kcal/mol) of their trifluoride derivatives. Data extracted from ref. [63].

\begin{tabular}{cccc}
\hline Pn & $\alpha$ & $\mathbf{R}_{\mathbf{v d W}}$ & MEP $\left(\mathbf{P n F}_{3}\right)$ \\
\hline $\mathrm{N}$ & 5.3 & 1.55 & 15.9 \\
\hline $\mathrm{P}$ & 16.9 & 1.80 & 27.4 \\
\hline $\mathrm{As}$ & 21.6 & 1.85 & 38.5 \\
\hline $\mathrm{Sb}$ & 30.8 & 2.06 & 46.7 \\
\hline
\end{tabular}




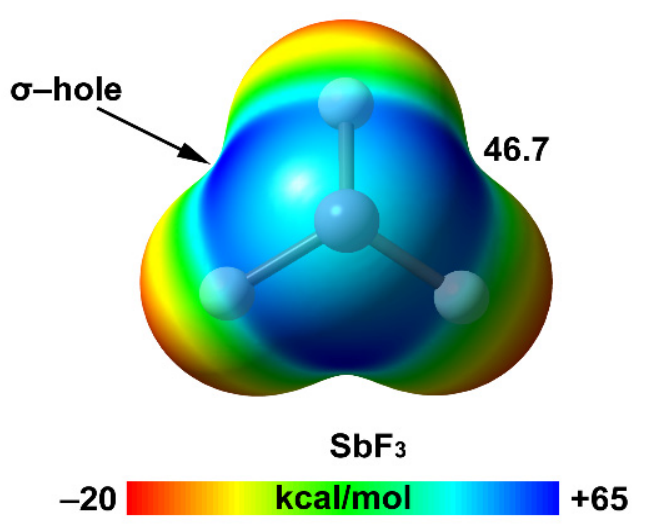

Figure 2. MEP surface of $\mathrm{SbF}_{3}$ at the MP2/def2-TZVP level of theory at the 0.001 a.u. isovalue (energy in $\mathrm{kcal} / \mathrm{mol}$ ).

Figure 2 shows the MEP surface of $\mathrm{SbF}_{3}$ as an illustrative example of the pnictogen group. As noted, it presents an ample region of positive MEP values where the global maximum is located approximately in the opposite direction to the $\mathrm{Sb}-\mathrm{F}$ bonds. In addition, the large and negative MEP values at the F-atoms reveal a strong polarization of the $\mathrm{Sb}-\mathrm{F}$ bonds.

\section{Arsenic and Antimony}

Arsenic and antimony are known to be involved in stronger PnBs than $\mathrm{N}$ and $\mathrm{P}$, as evidenced by the MEP analysis shown above. Their use as efficient anion binders [90] has been recently reported, with antimony being the most promising Pn atom to be used for anion recognition. In another study, Gabbaï and collaborators have reported bisstilbonium as a supramolecular synthon to build a preorganized host [91] involved in several PnBs interactions with electron-rich species. Additionally, Cozzolino and coworkers have synthesized anion receptors based on bidentate anion-binding motifs containing two $\mathrm{Sb}$ (III) centers, bridged by either oxygen or sulfur atoms acting as PnB donors [92].

In the field of organocatalysis, the number of studies devoted to the development of new functional PnB-based catalysts has rapidly increased during recent years [93-102]. In this section, several selected examples involving PnB-based catalysts are discussed. For each example an MEP surface of the Pn catalyst is shown, in addition to a plausible transition state/reaction intermediate stabilization scheme.

Benz and collaborators [93] compared the catalytic activity of a series of Pn catalysts using $\mathrm{P}$, As and $\mathrm{Sb}$ to their $\mathrm{Ch}$ (Se and $\mathrm{Te}$ ) and $\mathrm{Ha}(\mathrm{Br}$ and I) analogues. More precisely, the authors synthesized a series of phenyl and pentafluorophenyl (PFP)-substituted Pn, Ch and Ha moieties (see Table 2), and evaluated the dissociation constants ( $K_{D}$ values) of their corresponding chloride complexes by ${ }^{19} \mathrm{~F}$ NMR spectroscopic titration with TBACl in THF.

Table 2. Catalyst candidates used and dissociation constants $\left(K_{D}\right.$ in $\left.\mu \mathrm{M}\right)$ of chloride complexes in THF. Ph and PFP stand for phenyl and pentafluorophenyl moieties, respectively.

\begin{tabular}{|c|c|c|c|c|c|}
\hline Pn-Catalyst & $\mathrm{K}_{\mathrm{D}}$ & & & & \\
\hline $\mathrm{P}(\mathrm{PFP})_{3}$ & N/A & & & & \\
\hline $\mathrm{As}(\mathrm{PFP})_{3}$ & $13,300 \pm 800$ & & & & \\
\hline $\mathrm{Sb}(\mathrm{Ph})_{3}$ & N/A & & & & \\
\hline $\mathrm{Sb}(\mathrm{Ph})_{2} \mathrm{PFP}$ & $\mathrm{N} / \mathrm{A}$ & Ch-Catalyst & $K_{D}$ & Ha-Catalyst & $K_{D}$ \\
\hline $\mathrm{SbPh}(\mathrm{PFP})_{2}$ & $570 \pm 70$ & $\mathrm{Se}(\mathrm{PFP})_{2}$ & $27,000 \pm 4000$ & BrPFP & N/A \\
\hline $\mathrm{Sb}(\mathrm{PFP})_{3}$ & $19 \pm 7$ & $\mathrm{Te}(\mathrm{PFP})_{2}$ & $470 \pm 70$ & IPFP & $1370 \pm 30$ \\
\hline
\end{tabular}


Among them, $\mathrm{Sb}(\mathrm{PFP})_{3}$ (compound $\mathbf{1}$ ), gathered in Figure $3 \mathrm{a}$, achieved the best results in terms of dissociation constant $\left(\mathrm{K}_{\mathrm{D}}\right)$ of the chloride complex $(19 \pm 7 \mu \mathrm{M})$. As a likely explanation, the authors recalled the presence of three accessible $\sigma$-holes on the catalyst surface (only one is shown in Figure $3 \mathrm{~b}$ ) which exhibited MEP values of $+38.9 \mathrm{kcal} / \mathrm{mol}$.

Bearing these promising results in mind, Benz and collaborators successfully applied PnB catalysis to two organic reactions. The first was the Reissert-type substitution of isoquinoline, which is known to be catalyzed by different anion-binding catalysts [103-105]. As shown in Figure 4a, compound $\mathbf{1}$ accelerates the reaction by stabilizing the rate-limiting transition state 1(TS1), that is, the elimination of chloride following the addition of Troc chloride. In a posterior stage, the resulting cationic intermediate reacts with the nucleophile to afford products (TS2). Interestingly, after an initial screen of solvents and conditions, the authors obtained a $51 \%$ of yield within $30 \mathrm{~min}$ at $-100{ }^{\circ} \mathrm{C}$ in THF using $5 \mathrm{~mol} \%$ of catalyst.

(a)

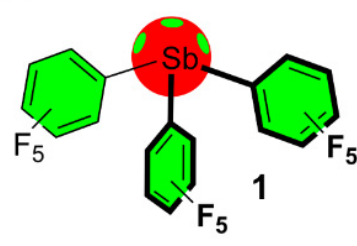

(b)

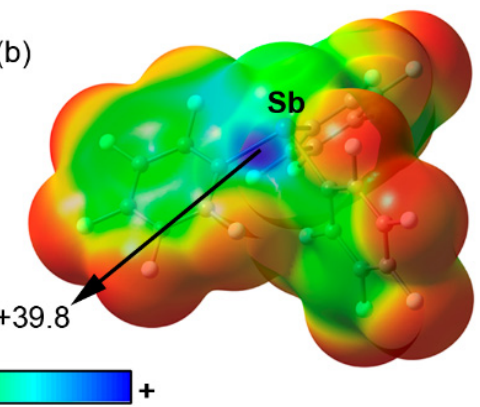

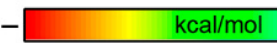

Figure 3. (a) Schematic representation and (b) MEP surface (0.001 a.u.) of compound 1 (B3LYP/def2TZVP level of theory) [93]. All MEP surfaces corresponding to Pn and Ch catalysts have been performed using the Gaussian16 calculation package [106].

(a)

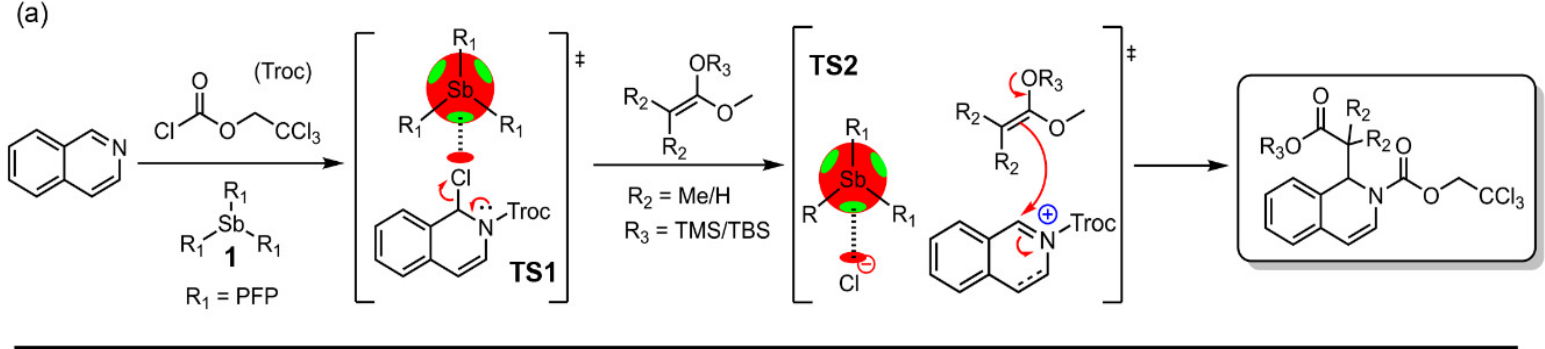

(b)

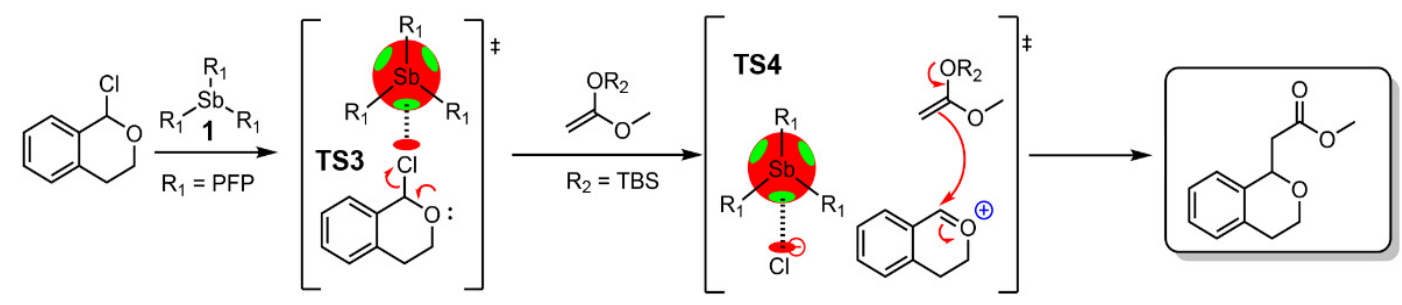

Figure 4. (a) Proposed reaction pathways of the Reissert-type substitution of isoquinolines and (b) the transformation of 1-chloroisochromane to an ester, including a schematic representation of the plausible stabilized transition states (TS1-4) through Sb-PnBs.

The authors also achieved success in catalyzing the more challenging transformation of 1-chloroisochromane to an ester, a reaction that proceeds through chloride abstraction in TS3 and successive attack of a silyl enol ether (see Figure $4 \mathrm{~b}$ ). The authors obtained a 91\% yield after $55 \mathrm{~h}$ at $-78{ }^{\circ} \mathrm{C}$ in THF using a $20 \mathrm{~mol} \%$ of compound 1 . In this case, both TS3 and 4 are also stabilized by $\mathrm{Sb} \cdots \mathrm{Cl}$ PnBs, which is similar to the Reissert-type substitution of isoquinolines, resulting in the corresponding ester. 
Additionally, Matile's group has carried out several studies on ether cyclization reactions [94-96,98]. In their study [96], Hao and collaborators carried out a comparative analysis of the use of electron-rich and electron-poor $\pi$-surfaces and PnB-based catalysts (see Figure 5 for some of the catalysts used) on bioinspired ether cyclization reactions. More precisely, the authors explored four epoxide-opening ether cyclizations as standards for the comparative assessment of catalytic systems.
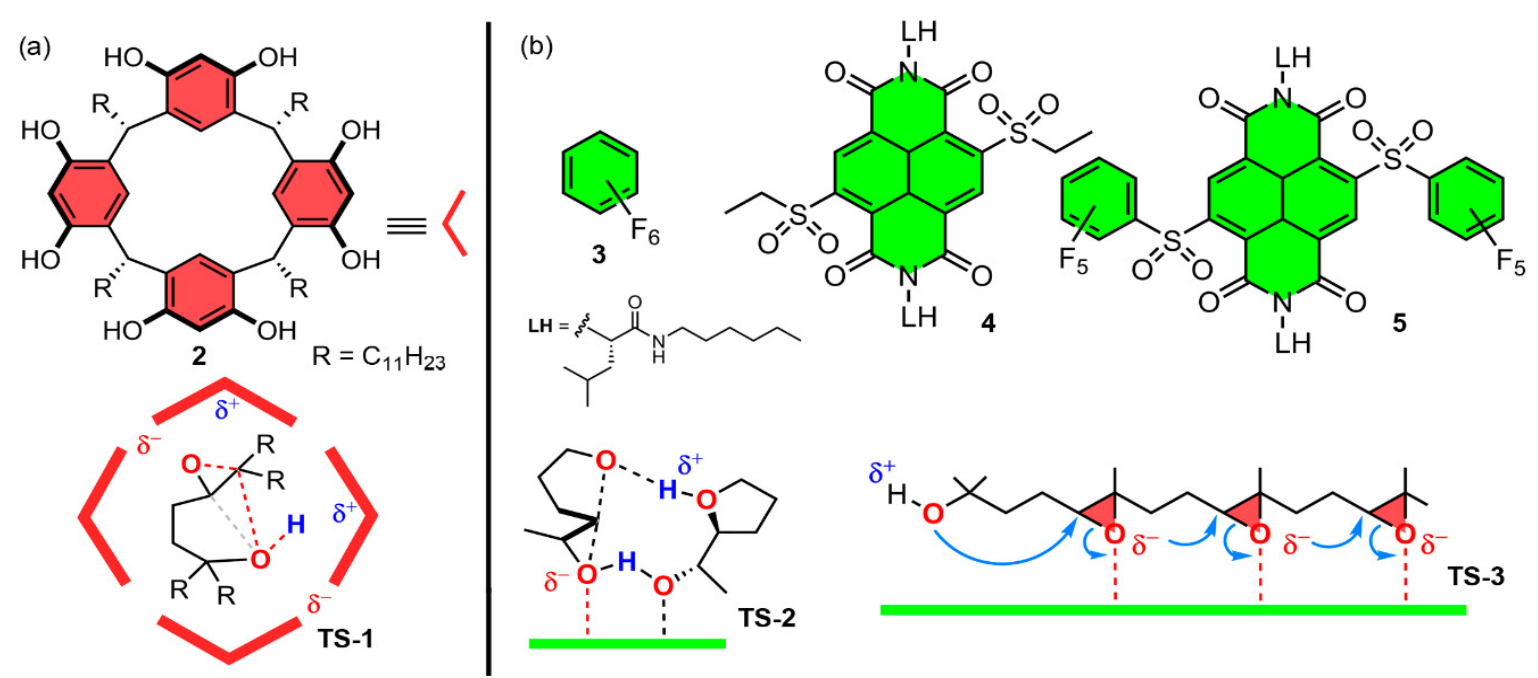

Figure 5. Schematic representation of several catalysts including (a) $\pi$-basic and (b) $\pi$-acid surfaces. The plausible transition states including cation $-\pi$ interactions in confined space of $\pi$-basic capsules (TS- 1 ) and anion- $\pi$ interactions in the cascade cyclization of a tetraepoxide (TS-2 and TS-3) are also included.

Firstly, the authors studied the ring-opening reaction of two ether derivatives (8 and $\mathbf{1 0})$ to yield products 9 and 11. In the first transformation (Figure 6a), the Baldwin-compatible 5-exo-tet oxolane product 9 was obtained using both capsule 2 and compound 3 as catalysts. Although the initial results were not promising, since for instance the conversion using hexafluorobenzene (3) as a solvent catalyst reached around $10 \%$ in $7 \mathrm{~h}$, the authors incremented the concentration of product 9 from the beginning of the reaction while using catalyst 2 , thus accelerating the rate of cyclization up to $\mathrm{k}_{\mathrm{cat}} / \mathrm{k}_{\mathrm{cat}(0)}=30 \pm 10$.

(a)

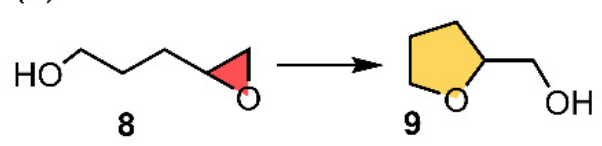

(b)

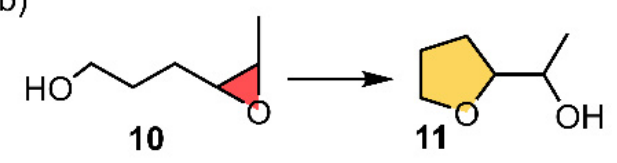

Figure 6. Schematic representation of two epoxide-opening ether cyclizations studied by Hao and collaborators [94] yielding compounds (a) 9 and (b) 11.

In a parallel way to substrate 8 , the cyclization of the 4,5-epoxy alcohol 10 with an extra methyl in the cis position on the epoxide solely yielded the Baldwin product $\mathbf{1 1}$ (Figure $6 \mathrm{~b}$ ). In this case, the reaction within capsule 2 was faster than that for the previous reaction (Figure 6a). Furthermore, the addition of extra product $\mathbf{1 1}$ at the beginning slowed down rather than accelerated the reaction, which was consistent with mildly competitive product encapsulation. On the other hand, the use of catalyst 3 achieved a faster conversion to product $\mathbf{1 1}$ and showed strongly autocatalytic behavior. In sharp contrast to the previous reaction, the addition of product $\mathbf{1 1}$ at the beginning of the cyclization of $\mathbf{1 0}$ using $\mathbf{3}$ did not accelerate conversion. However, the replacement of hexafluorobenzene solvent catalyst 3 by catalyst 4 , which exhibited a larger $\pi$ acidity (an electron-poor $\pi$ system), showed noticeable autocatalysis with 10. In Figure 5a,b, a schematic representation of the plausible transition states is shown (TS-1 and TS-2), involving the "accommodation" of the substrate 
within capsule 2 (TS-1) and the formation of two hydrogen bonds (one hydrogen-bond acceptor and one hydrogen-bond donor) in the activation of both nucleophile and leaving group in TS-2.

The authors also analyzed the cyclization of the 4,5-epoxy alcohol 12 with four extra methyl groups around the nucleophile and electrophile to yield the Baldwin oxolane product 13 together with the anti-Baldwin oxane product 14 (Figure 7a). In capsule 2, the reaction further accelerated, likely due to stabilization by cation $-\pi$ interactions (TS- 1 , Figure 5a). On the other hand, the use of hexafluorobenzene 3 revealed a similar result as in the case of compound 8 . In this scenario, the addition of product 13 at the beginning of the reaction of $\mathbf{1 2}$ in $\mathbf{3}$ accelerated the reaction noticeably, although not enough to surpass the results obtained using supramolecular capsule 2 , which performed better than the HB and $\mathrm{PnB}$ catalysts used (Figure 8). The latter accelerated the reaction though the establishment of multiple PnBs with the three available $\sigma$-holes present in the $\mathrm{Sb}$ atom and a lone pair- $\pi$ interaction involving the fluorinated ring moiety (TS-4).

(a)<smiles>CC(C)C1(C)CCC(C(C)(C)O)O1</smiles>

(b)<smiles>CC(C)(O)CCC1O[C@]1(C)CCC1OC1(C)CC1OC1(C)CC1CCC(C)(C)O1</smiles><smiles>[3H][Te]C1(C)CCC(O)C(C)(C)O1</smiles><smiles>CC1(C)CCC(O)C(C)(CCC2OC2(C)C)O1</smiles>

Figure 7. Schematic representation of two epoxide-opening ether cyclizations studied by Hao and collaborators [94] yielding compounds (a) 14 and (b) 16 to 19.
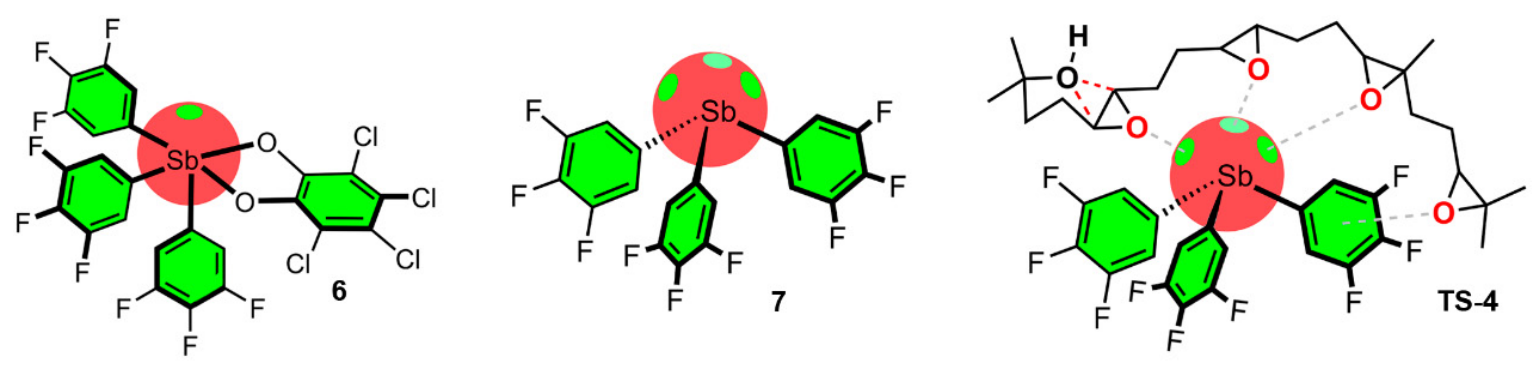

Figure 8. Schematic representation of several catalysts including multiple pnictogen bonding for cascade cyclization of a tetraepoxide on $\mathrm{Sb}(\mathrm{III})$ catalyst [94] (TS-4).

In the last stage of their study, diepoxide $\mathbf{1 5}$ was used, and the reaction followed ${ }^{1} \mathrm{H}$ NMR spectra (Figure $7 \mathrm{~b}$ ). In this case, 15 was initially used as a cis/trans mixture of isomers with a 6:4 ratio. The product mixtures contained the oxolane dimer 16 resulting from a cascade cyclization following Baldwin rules, the oxolane-oxane dimer $\mathbf{1 7}$ resulting from a Baldwin cyclization followed by an anti-Baldwin cyclization, and the fused bicycles 18 and 19 produced by an anti-Baldwin cyclization followed by a Baldwin and an antiBaldwin cyclization, respectively. Interestingly, the reaction carried out within capsule 2 afforded $\mathbf{1 7}$ as the main product, with high apparent diastereoselectivity, with only the one 16 diastereomer as a minor side product. The formation of 18 and 19, both produced from an initial anti-Baldwin cyclization, was almost completely suppressed. This diastereoselective formation of isomers of $\mathbf{1 7}$ could possibly be explained by the ability to fold into the most globular structure, as outlined in TS-1. 
Zhang and collaborators [97] developed a new family of chiral PnB-based catalysts (see Figure 9a). Concretely, 20 was obtained through the reaction of triarylstibine and mandelic acid under oxidative conditions and used as a catalyst in the reduction of benzoxazine with Hantzch ester (Figure 9b). After purification, the authors observed a decrease in the catalytic performance of $\mathbf{2 0}$ without noticing a clear decrease in enantioselectivity, as well as an unusual rate acceleration at the middle stage of the reaction. After further investigation, the authors assigned the catalytic active specie to the chiral antimony (V) cation/anion pair (compounds $\mathbf{2 1}$ and $\mathbf{2 2}$ in Figure 9a). As noticed in Figure 9c, the MEP surface analysis of 21 reveals an accessible and very positive $\mathrm{Sb} \sigma$-hole $(+86.6 \mathrm{kcal} / \mathrm{mol})$, which makes it a very strong $\mathrm{PnB}$ donor. This ion pair promoted the reduction of benzoxazine efficiently in $2 \mathrm{~h}$, obtaining the product with $99 \%$ yield with $80 \%$ ee.

(a)<smiles>O=C(O[Sb](c1ccccc1)(c1ccccc1)c1ccccc1)c1ccccc1</smiles>

(b)

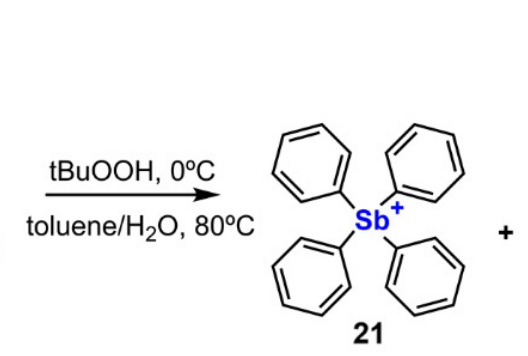

chiral ion pair PnB catalyst

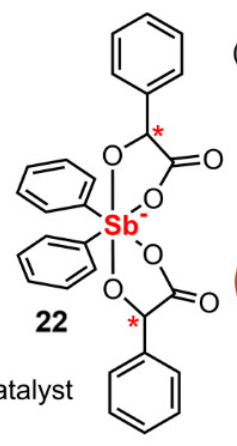

(c)

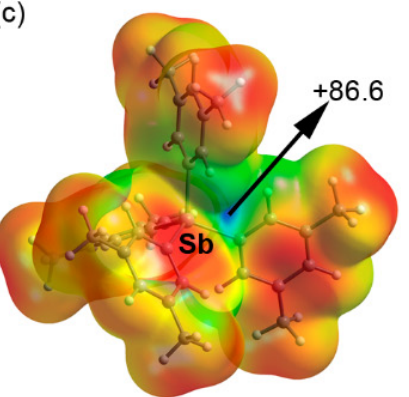

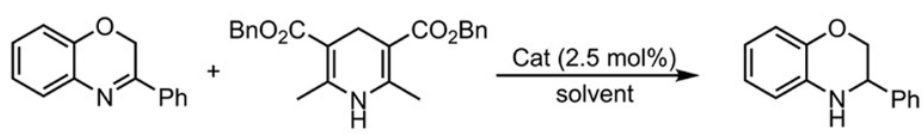

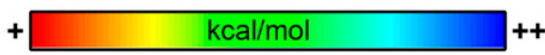

Figure 9. (a) Schematic representation of the synthetic procedure to obtain the chiral ion pair PnB catalyst (the methyl groups bound to the benzene rings have been omitted for sake of clarity), (b) reaction scheme of the benzoxanine reduction with Hantzch ester and (c) MEP surface of compound 21 (B3LYP/def2-TZVP). The energy value shown at the selected point in the surface is given in $\mathrm{kcal} / \mathrm{mol}$ (0.001 a.u.). Chiral centers are denoted by a red * in the figure.

Consequently, compound $\mathbf{2 0}$ analogues with different mandelic acid ligands were prepared and tested in different reaction conditions. On the other side, different substituents were used in benzoxazine to assess their influence on the reaction global performance. Lastly, to gain mechanistic insights into the chiral antimony $(\mathrm{V})$ cation/anion pair catalyzed asymmetric transfer hydrogenation, nonlinear effect studies were conducted. The authors observed a weak negative nonlinear relationship between ee of the catalyst and ee of the product. This phenomenon indicated the presence of ligand exchange and/or catalyst aggregation during the course of the reaction, which was further confirmed by ${ }^{1} \mathrm{H}$ NMR spectra [97].

The last selected example of PnB catalysis encompasses the study from Yang and coworkers [98] where they synthesized monodentate and bidentate phosphonium-stilbonium and bis-stilbonium cations as PnB catalysts. More precisely, bidentate Pn compounds 22 and 23 were synthesized and X-ray characterized. Both of them are dications, therefore bearing either one $\mathrm{Sb}(\mathrm{III})$ and one $\mathrm{P}(\mathrm{III})$ or two $\mathrm{Sb}(\mathrm{III})$ in their structure (see Figure 10). As noticed, their corresponding MEP surfaces exhibit very positive $\mathrm{Sb}$ and $\mathrm{P} \sigma$-holes. In the case of compound 22, only the Sb $\sigma$-hole was accessible with an MEP value of $+201.4 \mathrm{kcal} / \mathrm{mol}$, whilst in compound 23 both $\mathrm{Sb} \sigma$-holes presented spatial accessibility and an MEP value of $+212.7 \mathrm{kcal} / \mathrm{mol}$ (B3LYP/def2-TZVP level of theory). 
(a)

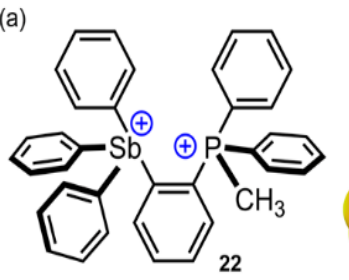

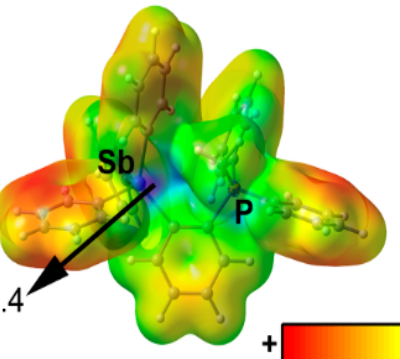

(b)

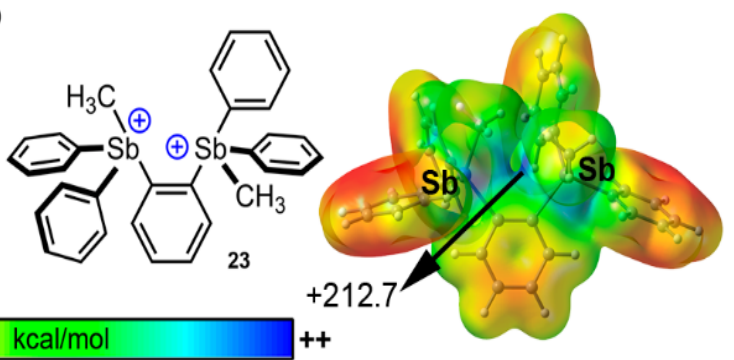

Figure 10. (a) Schematic representation of compounds 22 and 23 and (b) their corresponding MEP surfaces. Energies at the selected points of the surface are given in $\mathrm{kcal} / \mathrm{mol}(0.035 \mathrm{a} . \mathrm{u}$.).

In a similar way to the study of Zhang and collaborators [97], Yang et al. used compounds 22 and 23 as catalysts for the transfer hydrogenation reaction between Hantzch ester and quinolines (see Figure 9b,10). Furthermore, the authors also synthesized monostilbonium cations, which presented lower catalytic activity compared to bidentated Pn catalysts $\mathbf{2 2}$ and 23. Particularly, the use of $\mathbf{2 2}$ afforded a conversion of $90 \%$ after $1 \mathrm{~h}$, which was assigned to the presence of two adjacent cationic Sb centers which can actuate in a cooperative way to activate the substrate.

Finally, DFT calculations were used to simulate the double activation of the substrate by the dicationic systems, a step that would precede transfer of a hydride from the Hantzsch ester. Using a simplified computational model, the authors predict the lowest energy binding mode between the substrate and the catalyst (see Figure 11). As noted, for both catalysts 22 and 23 , a bifurcated $\mathrm{N} \cdots \mathrm{Sb} / \mathrm{P} \mathrm{PnB}$ was proposed in addition to a stacking interaction involving the $\pi$-systems of the quinoline and a phenyl ring bound to one of the Pn atoms, which further assisted in the stabilization of the supramolecular complex.
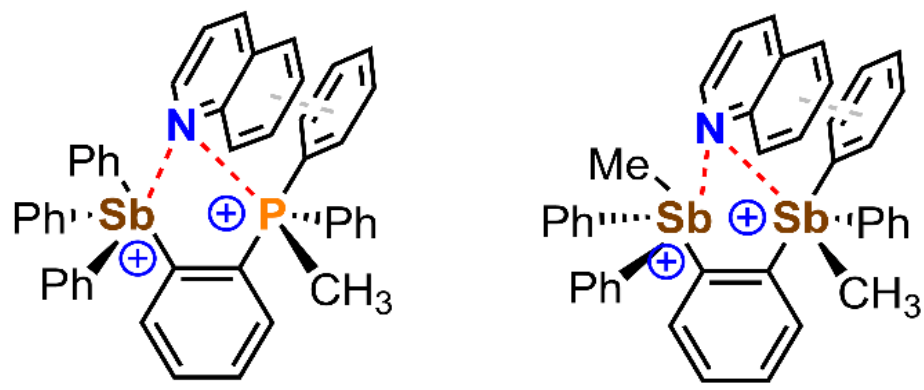

Figure 11. Schematic representation of the plausible transition state stabilization through bifurcated $\mathrm{PnB}$ and $\pi-\pi$ stacking interactions involving compounds 22 and 23.

\subsection{Chalcogen Bonding}

Among chalcogens, organotellurium compounds such as tellurophene and bis(tellurophene) derivatives are gaining interest in supramolecular catalysis and anion recognition phenomena [11,107-111].

In Table 3, the atomic polarizabilities $(\alpha)$ and van der Waals radii of the chalcogen elements from period two to five are displayed. As noted, the atomic $\alpha$ value increases from 3.0 a.u. in $\mathrm{O}$ to 25.9 a.u. in Te. Interestingly, the difference in the atomic polarizability between $\mathrm{O}$ and $\mathrm{S}$ is quite large $(\sim 4 \mathrm{x})$, which is in line with the behavior observed in Pn atoms. On the contrary, the differences between $\mathrm{S}$ and Se or Se and Te are negligible. The MEP values at the $\sigma$-holes of the fluoride derivatives of the four $\mathrm{Ch}$ elements studied in this section are also given in Table 3, and the MEP for $\mathrm{TeF}_{2}$ molecule is represented in Figure 12. They show the expected trend with $\sigma$-hole values increasing from $16.8 \mathrm{kcal} / \mathrm{mol}$ in $\mathrm{OF}_{2}$ to $52.6 \mathrm{kcal} / \mathrm{mol}$ in $\mathrm{TeF}_{2}$. 
Table 3. Atomic polarizabilities ( $\alpha$, a.u.) of chalcogen $(\mathrm{Ch})$ elements, van der Waals radii $\left(\mathrm{R}_{\mathrm{vdW}}, \AA\right)$ and $\sigma$-hole MEP values (MEP, $\mathrm{kcal} / \mathrm{mol}$ ) of their difluoride derivatives taken from ref. [63].

\begin{tabular}{cccc}
\hline Ch & $\alpha$ & $\mathbf{R}_{\mathbf{v d W}}$ & MEP $\left(\mathbf{C h F}_{\mathbf{2}}\right)$ \\
\hline $\mathrm{O}$ & 3.0 & 1.52 & 16.8 \\
\hline $\mathrm{S}$ & 11.8 & 1.80 & 35.6 \\
\hline $\mathrm{Se}$ & 17.5 & 1.90 & 44.9 \\
\hline $\mathrm{Te}$ & 25.9 & 2.06 & 52.6 \\
\hline
\end{tabular}

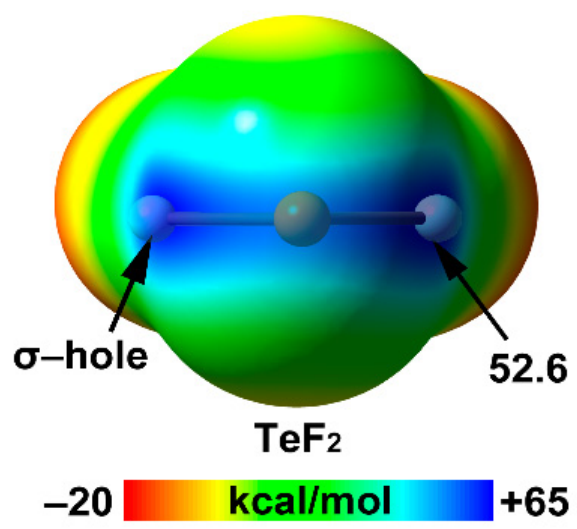

Figure 12. MEP surface of $\mathrm{TeF}_{2}$ using the 0.001 a.u. isosurface at the MP2/def2-TZVP level of theory (energy in $\mathrm{kcal} / \mathrm{mol}$ ).

Figure 12 shows the MEP surfaces of $\mathrm{TeF}_{2}$ as an illustrative example of the whole series. As noted, $\mathrm{TeF}_{2}$ exhibits an extended region of positive MEP values in the molecular plane, with two $\sigma$-holes located approximately on the extension of the F-Te bonds. A similar behavior is observed in $\mathrm{SbF}_{3}$ (see Figure 2).

\section{Selenium and Tellurium}

Several studies available in the literature are focused on direct applications of ChB in catalysis [112-126], showing interesting and clever ways of the use of ChBs to stabilize negatively charged transition states.

In 2017, Benz and collaborators [112] proposed neutral benzodiselenazole (BDS) as a prototypical molecular synthon for the catalysis of the transfer hydrogenation of quinolines (see Figure 13). Concretely, the authors proposed several functionalized BDS as structural motifs involving Se $\mathrm{ChB}$ donors using zero, one or two sulfoxide moieties and the substituents $\mathrm{R}^{1}$ and $\mathrm{R}^{2}$, which accounted for $\mathrm{CN}, \mathrm{CH}_{3}$ and iBu groups $\left(\mathrm{R}^{1}\right)$ and paratercbutylphenyl (PTBP), adamantane and octyl groups $\left(R^{2}\right)$ (see Figure 13a). In this regard, the MEP analysis of one of the most promising candidates (24, see Figure 13b), as the ChB donor is shown. As noticed, two strong Se $\sigma$-holes are present, located along the C-Se bonds and overlapping between the Se atoms $(+31.7 \mathrm{kcal} / \mathrm{mol})$.

Using the ChB-donor ability of $\mathbf{2 4}$, the authors demonstrated its catalytic activity in the hydrogenation reaction of quinolines (see Figure 14) through a transition-state stabilization in the focal point of the Se $\sigma$-holes of the BDS. Concretely, in the transition state, the negative charge carried out by the hydride is located on the endocyclic nitrogen, which can be stabilized through the formation of a bifurcated Se ChB, therefore resulting in rate enhancement of the transfer hydrogenation. The authors reported a catalytic rate enhancement of five orders of magnitude by compound 24, with presented maximized $\sigma$-holes by two strong sulfone- and two strong cyano-acceptors. 
(a)

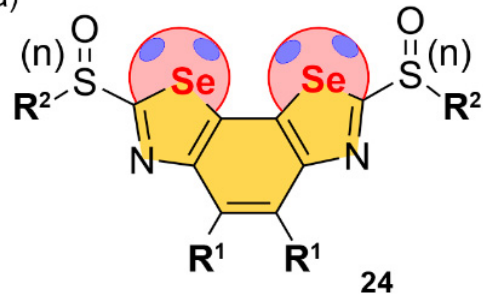

(b)

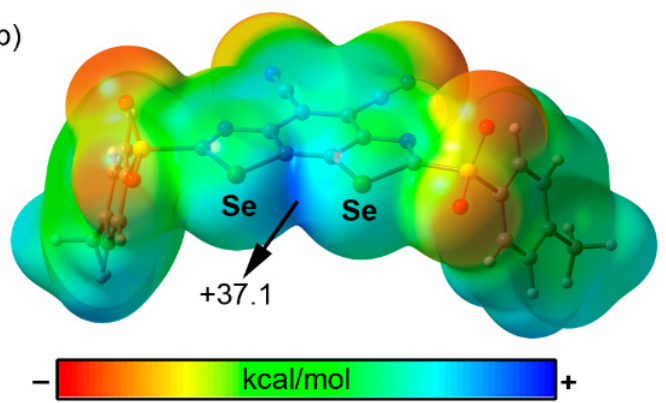

Figure 13. (a) Schematic representation of compound 24 (PTBP stands for para-tercbutylphenyl) and (b) its MEP surface at the B3LYP/def2-TZVP level of theory. The energy value at the selected point of the surface is given in $\mathrm{kcal} / \mathrm{mol}$ (0.001 a.u.).

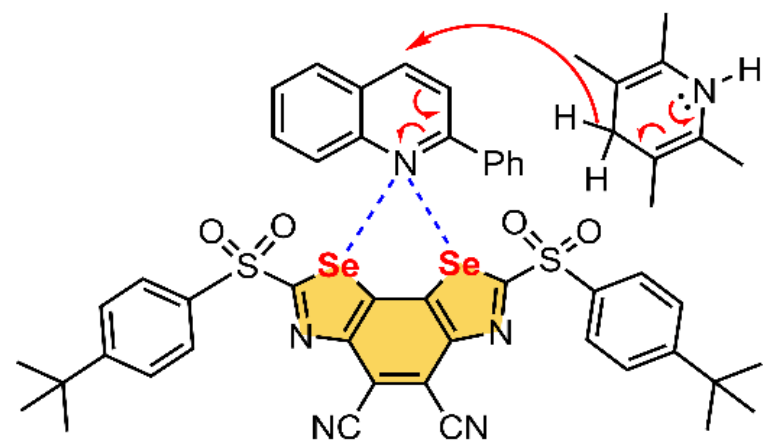

Figure 14. Schematic representation of the expected transition-state stabilization by a bifurcated Se ChB, involving compound 24.

Other interesting examples are the studies by Wang [113,114] and Bao [115] and collaborators, which effectively designed a series of catalysts based on $\mathrm{Ch} \cdots \mathrm{Ch}$ interactions. In one of their works [114], the authors carried out the synthesis, X-ray and NMR characterization and the evaluation of the catalytic activity of a series of $\mathrm{ChB}$ catalysts for the Rauhut-Currier reaction based on dual Se $\cdots \mathrm{O}$ ChBs (see Figure 15 for one of the most promising candidates). As noticed, there are two available Se $\sigma$-holes on the catalyst which exhibit an electrostatic potential value of $+142.5 \mathrm{kcal} / \mathrm{mol}$, owing to the positively charged nature of the molecule.

(a)

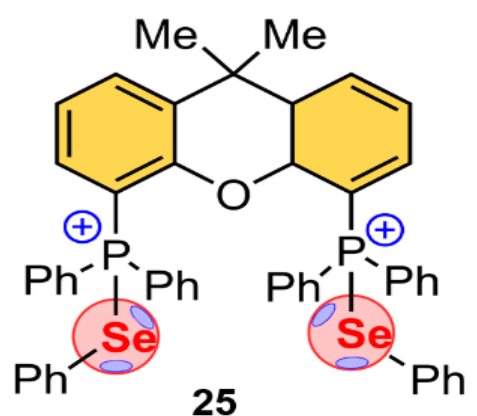

(b)

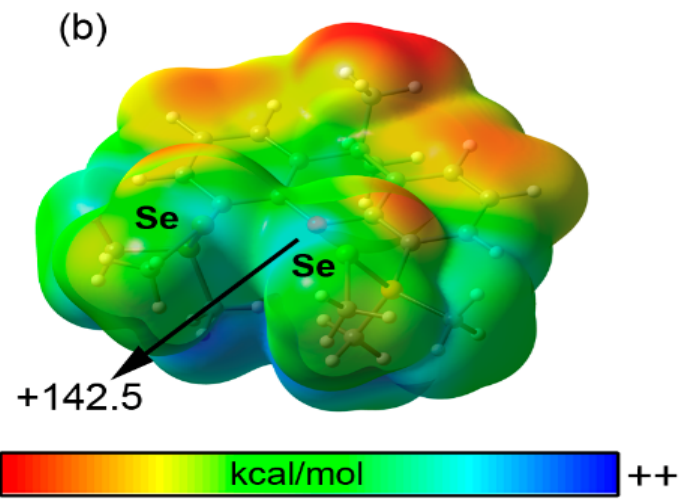

Figure 15. (a) Schematic representation of compound 25 and (b) its MEP surface at the B3LYP/def2TZVP level of theory (Ph groups have been replaced by Me groups for sake of clarity). Energy value in $\mathrm{kcal} / \mathrm{mol}$ (0.001 a.u.). 
The dual binding ability of this family of catalysts was used to interact with the two nucleophile species needed for the Rauhut-Currier reaction, which are an enone and an alcohol. Particularly, the simultaneous interaction of a ChB catalyst with these two reactants provoked a shift from the intermolecular alcohol addition of enone to an "intramolecular" manner, thus facilitating the addition process (see Figure 16 for the proposed reaction mechanism and transition state stabilization). To verify this hypothesis, the authors performed several experiments, altering the concentrations of either of the nucleophiles or modifying the substituents of the Se atom to evaluate the effect of the steric hindrance of the catalytic activity. They concluded that a proper balance between the concentrations of the two electron donors is essential, as the catalyst needs to simultaneously interact with both the alcohol and the enone to drive this reaction.

(a)

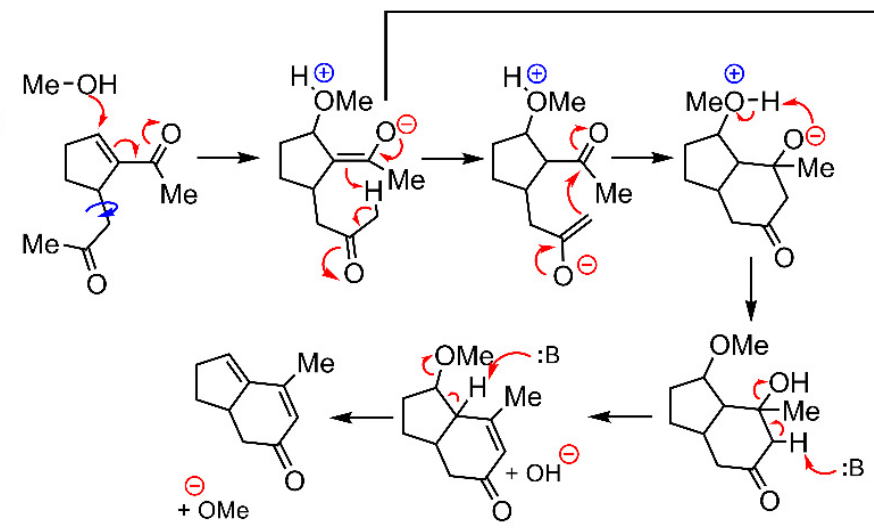

(b)

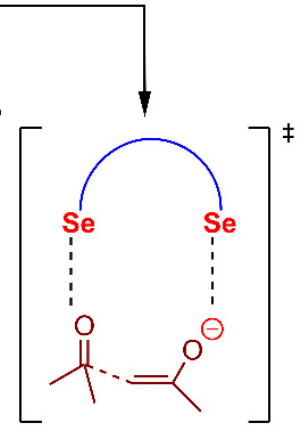

Figure 16. (a) Proposed reaction pathway of the Rauhut-Currier reaction and (b) Schematic representation of the plausible stabilized transition state through a dual $\mathrm{ChB}$ interaction.

In 2019, Wonner and collaborators [116] proposed the synthesis and catalytic activity of a series of $\mathrm{Ch}$-based organocatalyts. Figure 17 shows the chemical structure and MEP surface of compound 26, a tellurium-based catalyst which exhibited a promising activity for the nitro Michael reaction. As noted in Figure 17b, the MEP surface of this compound shows two very positive electrostatic potential regions corresponding to the location of two Se $\sigma$ holes $(+141.8 \mathrm{kcal} / \mathrm{mol})$. Similarly, in the previous study from Wang and collaborators [113], the cationic nature of the catalyst provokes and enhancement of the $\sigma$-hole donor ability of the Te atoms. The authors achieved better reaction yields when using low coordinating counterions (such as $\mathrm{BF}_{4}$ or BARF), suggesting a higher accessibility of the Te $\sigma$-holes.

(a)

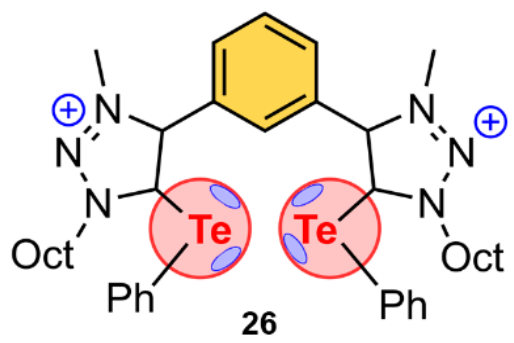

(b)

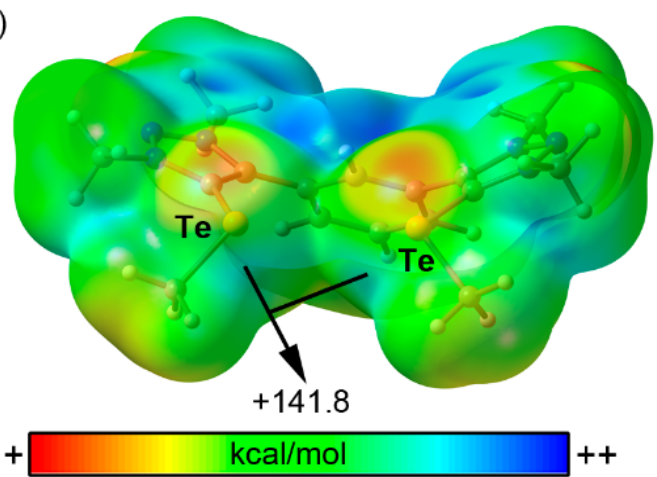

Figure 17. (a) Schematic view of compound 26 and (b) its MEP surface analysis at the B3LYP/def2TZVP level of theory ( $\mathrm{Ph}$ and Oct groups have been replaced by Me groups for sake of clarity). Energy value in $\mathrm{kcal} / \mathrm{mol}$ (0.001 a.u.). 
The proposed mechanism of action is shown in Figure 18, and as noted, compound $\mathbf{2 6}$ undergoes two simultaneous $\mathrm{ChBs}$ with the two negatively charged $\mathrm{O}$ atoms from the nitro derivative, thus likely stabilizing the reaction intermediate. This aspect was further demonstrated by DFT calculations (M062X-D3/def2-TZVP level of theory) which proposed $\mathrm{Te} \cdots \mathrm{O}$ distances of 2.49 and $2.53 \AA$ and $\mathrm{C}-\mathrm{Te} \cdots \mathrm{O}$ angles of 166 and $168^{\circ}$, in line with two directional ChB interactions.

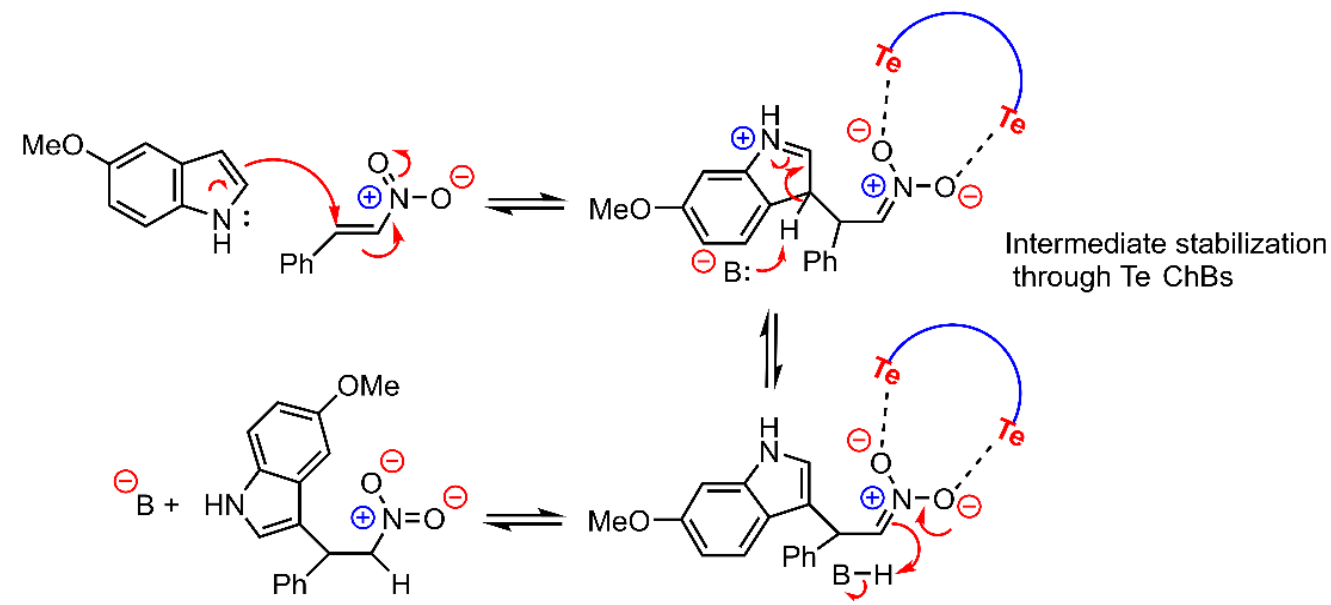

Figure 18. Schematic representation of the proposed reaction pathway for the nitro Michael reaction catalyzed by compound $\mathbf{2 6}$ with a plausible stabilization of the reaction intermediate through two simultaneous ChBs.

As the final example, Weiss and collaborators [117] designed and synthesized a Tellurium organocatalyst (compound 27, Figure 19a), able to efficiently catalyze three different reactions: the Friedel-Crafts bromination of anisole, the bromolactonization of $\omega$-unsaturated carboxylic acids and the aza-Diels-Alder reaction between Danisehfsky's diene and imines. In Figure 19b the MEP surface of compound 27 is shown, which involves $\mathrm{CF}_{3}$ substitution in both benzene rings. As noted, the MEP value around the three available Te $\sigma$-holes is very positive $(+125.5 \mathrm{kcal} / \mathrm{mol})$, which makes it suitable for the establishment of strong Te ChBs.

(a)<smiles>C[Ge](c1cc(C(F)(F)F)cc(C(F)(F)F)c1)(c1cc(C(F)(F)F)cc(C(F)(F)F)c1)C(F)(F)F</smiles>

(b)

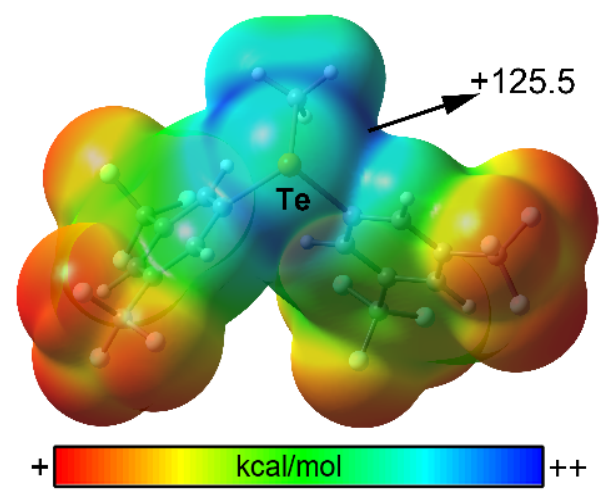

Figure 19. (a) Schematic view of compound 27 and (b) MEP surface of the catalyst at the B3LYP/def2TZVP level of theory. Energy value in $\mathrm{kcal} / \mathrm{mol}$ (0.001 a.u.).

The authors used the three reactions shown in Figure 20 as benchmark tests to evaluate the effectiveness of Te catalyst 27. Concretely, in the Friedel-Crafts bromination of anisole (Figure 20a), the authors used two aromatic substituents (-OMe and $\left.-\mathrm{CF}_{3}\right)$, obtaining very high yields in all the cases $(80-90 \%)$. However, those catalysts using $\left[\mathrm{BArF}_{4}\right]^{-}$as a counterion achieve the best results, in agreement with previous studies [114], likely due to a greater Te $\sigma$-hole availability. They concluded that increasing or decreasing the catalyst 
amount did not affect the catalyst efficiency, and interestingly, even $0.5 \mathrm{~mol} \%$ of catalyst still promoted this reaction very efficiently within $5 \mathrm{~min}$. Finally, the authors also confirmed the catalyst stability by performing NMR monitoring of the reaction.<smiles>COc1ccc(Br)c(I)c1</smiles><smiles>C=CCC(=O)OC1CC(CBr)C(=O)N1Br</smiles>

(c)<smiles>[R]c1ccc(/C=N/c2ccc([R])cc2)cc1</smiles>

$\mathrm{R}=\mathrm{H}, \mathrm{OMe}, \mathrm{NO}_{2}$

Figure 20. Schematic view of the three benchmark reactions used to evaluate the efficiency of the Te organocatalysts. (a) Friedel-Crafts bromination of anisole. (b) Bromolactonization of $w$-unsaturated carboxylic acids. (c) Aza-Diels-Alder reaction between Danisehfsky's diene and imines.

The second benchmark reaction used was the bromolactonization of $\omega$-unsaturated carboxylic acids (Figure 20b). Concretely, a series of $\omega$-unsaturated carboxylic acids was submitted to NBS in the presence of telluronium catalyst shown in Figure 20a. Interestingly, the expected bromolactones were obtained within $30 \mathrm{~min}$ in good quantitative yields for 4-to-6-membered rings, although in lower yields for larger rings, while no reaction occurred without the catalyst. The authors also confirmed the stability of the catalyst during the reaction. Finally, the authors further tested compound 27 on the aza-Diels-Alder-type reaction, using the Danishefsky's diene condensation with various imines as a prototypical reaction. In this case, all the examined imines readily afforded the expected $\mathrm{N}$-phenyl 2,3-dihydro-4-pyridinones in good-to-high yields with only $1 \mathrm{~mol} \%$ of catalyst within $2 \mathrm{~h}$ at room temperature.

\section{Conclusions}

The data of MEP and polarizability data summarized in this review show that the polarizability of the p-block elements increases when moving from period two to five, with large differences between periods two and three. Moreover, the MEP values increase when descending in the group, similarly to the behavior observed for the polarizability. The selected examples shown in Sections 2.1 and 2.2 of this review, which is not intended to be comprehensive, give significant experimental support to the fact that the elements from groups 15 and 16 have a strong tendency to establish directional $\mathrm{PnB}$ and $\mathrm{ChB}$ interactions with Lewis bases or anions. This in turn can be used for the stabilization of reaction intermediates as well as transition states, thus accelerating and improving reaction rates. Although the applications of these novel NCIs in this field of research are in its mere naissance, the use of catalysts based on PnB and ChB interactions should be considered and used by the scientific community as a novel and efficient tool in the field of organocatalysis.

Author Contributions: Conceptualization, A.F. and A.B.; methodology, A.F. and A.B.; software, A.F. and A.B.; investigation, A.F. and A.B.; writing-original draft preparation, A.B. and A.F., writingreview and editing, A.F. and A.B., visualization, A.F. and A.B., project administration, A.F.; funding acquisition, A.F. All authors have read and agreed to the published version of the manuscript. 
Funding: This research was funded by the MICIU/AEI of Spain (project PID2020-115637GB-I00 FEDER funds).

Acknowledgments: We thank the "Centre de Tecnologies de la Informació" (CTI), Universitat de les Illes Balears for computational facilities.

Conflicts of Interest: The authors declare no conflict of interest.

\section{References}

1. Pizzi, A.; Pigliacelli, C.; Bergamaschi, G.; Gori, A.; Metrangolo, P. Biomimetic engineering of the molecular recognition and self-assembly of peptides and proteins via halogenation. Coord. Chem. Rev. 2020, 411, 213242. [CrossRef]

2. Daolio, A.; Scilabra, P.; Terraneo, G.; Resnati, G. C( $\left.\mathrm{sp}^{3}\right)$ atoms as tetrel bond donors: A crystallographic survey. Coord. Chem. Rev. 2020, 413, 213265. [CrossRef]

3. Von der Heiden, D.; Vanderkooy, A.; Erdélyi, M. Halogen bonding in solution: NMR spectroscopic approaches. Coord. Chem. Rev. 2020, 407, 213147. [CrossRef]

4. Gill, H.; Gokel, M.R.; McKeever, M.; Negin, S.; Patel, M.B.; Yin, S.; Gokel, G.W. Supramolecular pore formation as an antimicrobial strategy. Coord. Chem. Rev. 2020, 412, 213264. [CrossRef]

5. Xu, Y.; Szell, P.M.J.; Kumar, V.; Bryce, D.L. Solid-state NMR spectroscopy for the analysis of element-based non-covalent interactions. Coord. Chem. Rev. 2020, 411, 213237. [CrossRef]

6. Wang, W.; Zhang, Y.; Jin, W.J. Halogen bonding in room-temperature phosphorescent materials. Coord. Chem. Rev. 2020, 404, 213107. [CrossRef]

7. Grabowski, S.J. Triel bond and coordination of triel centres-Comparison with hydrogen bond interaction. Coord. Chem. Rev. 2020, 407, 213171. [CrossRef]

8. Fromm, K.M. Chemistry of alkaline earth metals: It is not all ionic and definitely not boring! Coord. Chem. Rev. 2020, 408, 213192. [CrossRef]

9. Fourmigué, M.; Dhaka, A. Chalcogen bonding in crystalline diselenides and selenocyanates: From molecules of pharmaceutical interest to conducting materials. Coord. Chem. Rev. 2020, 403, 213084. [CrossRef]

10. Scheiner, S.; Michalczyk, M.; Zierkiewicz, W. Coordination of anions by noncovalently bonded $\sigma$-hole ligands. Coord. Chem. Rev. 2020, 405, 213136. [CrossRef]

11. Taylor, M.S. Anion recognition based on halogen, chalcogen, pnictogen and tetrel bonding. Coord. Chem. Rev. 2020, 413, 213270. [CrossRef]

12. Bauzá, A.; Frontera, A. $\sigma / \pi$-Hole noble gas bonding interactions: Insights from theory and experiment. Coord. Chem. Rev. 2020, 404, 213112. [CrossRef]

13. Biot, N.; Bonifazi, D. Chalcogen-bond driven molecular recognition at work. Coord. Chem. Rev. 2020, 413, 213243. [CrossRef]

14. Cavallo, G.; Metrangolo, P.; Pilati, T.; Resnati, G.; Terraneo, G. Naming interactions from the electrophilic site. Cryst. Growth Des. 2014, 14, 2697-2702. [CrossRef]

15. Terraneo, G.; Resnati, G. Bonding Matters. Cryst. Growth Des. 2017, 17, 1439-1440. [CrossRef]

16. Desiraju, G.R.; Ho, P.S.; Kloo, L.; Legon, A.C.; Marquardt, R.; Metrangolo, P.; Politzer, P.; Resnati, G.; Rissanen, K. Definition of the halogen bond (IUPAC Recommendations 2013). Pure Appl. Chem. 2013, 85, 1711-1713. [CrossRef]

17. Aakeroy, C.B.; Bryce, D.L.; Desiraju, G.R.; Frontera, A.; Legon, A.C.; Nicotra, F.; Rissanen, K.; Scheiner, S.; Terraneo, G.; Metrangolo, P.; et al. Definition of the chalcogen bond (IUPAC Recommendations 2019). Pure Appl. Chem. 2019, 91, 1889-1892. [CrossRef]

18. Zahn, S.; Frank, R.; Hey-Hawkins, E.; Kirchner, B. Pnicogen bonds: A new molecular linker? Chem. Eur. J. 2011, 17, $6034-6038$. [CrossRef] [PubMed]

19. Alkorta, I.; Elguero, J.; Frontera, A. Not only hydrogen bonds: Other noncovalent interactions. Crystals 2020, 10, 180. [CrossRef]

20. Bauzá, A.; Mooibroek, T.J.; Frontera, A. Tetrel Bonding Interaction: Rediscovered Supramolecular Force? Angew. Chem. Int. Ed. 2013, 52, 12317-12321. [CrossRef]

21. Daolio, A.; Pizzi, A.; Terraneo, G.; Frontera, A.; Resnati, G. $\sigma$-Holes Allow for Attractive Anion $\cdots$ anion Interactions Involving Perrhenate, Permanganate, and Pertechnetate Anions. ChemPhysChem 2021, 22, accepted. [CrossRef]

22. Daolio, A.; Pizzi, A.; Calabrese, M.; Terraneo, G.; Bordignon, S.; Frontera, A.; Resnati, G. Molecular Electrostatic Potential and Noncovalent Interactions in Derivatives of Group 8 Elements. Angew. Chem. Int. Ed. 2021, 60, 20723-20727. [CrossRef]

23. Bauzá, A.; Alkorta, I.; Elguero, J.; Mooibroek, T.J.; Frontera, A. Spodium Bonds: Noncovalent Interactions Involving Group 12 Elements. Angew. Chem. Int. Ed. 2020, 59, 17482-17487. [CrossRef] [PubMed]

24. Stenlid, J.H.; Johansson, A.J.; Brinck, T. $\sigma$-Holes and $\sigma$-lumps direct the Lewis basic and acidic interactions of noble metal nanoparticles: Introducing regium bonds. Phys. Chem. Chem. Phys. 2018, 20, 2676-2692. [CrossRef]

25. Daolio, A.; Pizzi, A.; Terraneo, G.; Ursini, M.; Frontera, A.; Resnati, G. Anion ‥Anion Coinage Bonds: The Case of Tetrachloridoaurate. Angew. Chem. Int. Ed. 2021, 60, 14385-14389. [CrossRef] [PubMed]

26. Frontera, A.; Bauzá, A. Regium $-\pi$ bonds: An Unexplored Link between Noble Metal Nanoparticles and Aromatic Surfaces. Chem. Eur. J. 2018, 24, 7228-7234. [CrossRef]

27. Terrón, A.; Buils, A.; Mooibroek, T.J.; Barceló, M.; García-Raso, A.; Fiol, J.J.; Frontera, A. Synthesis, X-ray characterization and regium bonding interactions of a trichlorido(1-hexylcytosine)gold(III) complex. Chem. Commun. 2020, 56, 3524-3527. [CrossRef]

28. Politzer, P.; Lane, P.; Concha, M.C.; Ma, Y.; Murray, J.S. An overview of halogen bonding. J. Mol. Model. 2007, 13, 305-311. [CrossRef]

29. Metrangolo, P.; Resnati, G. Halogen bonding: A paradigm in supramolecular chemistry. Chem. Eur. J. 2001, 7, 2511-2519. [CrossRef] 
30. Metrangolo, P.; Neukirch, H.; Pilati, T.; Resnati, G. Halogen bonding based recognition processes: A world parallel to hydrogen bonding. Acc. Chem. Res. 2005, 38, 386-395. [CrossRef]

31. Metrangolo, P.; Meyer, F.; Pilati, T.; Resnati, G.; Terraneo, G. Halogen bonding in supramolecular chemistry. Angew. Chem. Int. Ed. 2008, 47, 6114-6127. [CrossRef]

32. Metrangolo, P.; Resnati, G. (Eds.) Halogen Bonding: Fundamentals and Applications; Springer: Berlin/Heidelberg, Germany, 2008.

33. Politzer, P.; Murray, J.S.; Clark, T. Halogen bonding: An electrostatically-driven highly directional noncovalent interaction. Phys. Chem. Chem. Phys. 2010, 12, 7748-7757. [CrossRef]

34. Erdélyi, M. Halogen bonding in solution. Chem. Soc. Rev. 2012, 41, 3547-3557. [CrossRef] [PubMed]

35. Beale, T.M.; Chudzinski, M.G.; Sarwar, M.G.; Taylor, M.S. Halogen bonding in solution: Thermodynamics and applications. Chem. Soc. Rev. 2013, 42, 1667-1680. [CrossRef] [PubMed]

36. Politzer, P.; Murray, J.S.; Clark, T. Halogen bonding and other $\sigma$-hole interactions: A perspective. Phys. Chem. Chem. Phys. 2013, 15, 11178-11189. [CrossRef]

37. Metrangolo, P.; Resnati, G. (Eds.) Halogen Bonding II Impact on Materials Chemistry and Life Sciences; Springer International Publishing AG: Heidelberg, Germany, 2015.

38. Gilday, L.C.; Robinson, S.W.; Barendt, T.A.; Langton, M.J.; Mullaney, B.R.; Beer, P.D. Halogen bonding in supramolecular chemistry. Chem. Rev. 2015, 115, 7118-7195. [CrossRef]

39. Cavallo, G.; Metrangolo, P.; Milani, R.; Pilati, T.; Priimagi, A.; Resnati, G.; Terraneo, G. The halogen bond. Chem. Rev. 2016, 116, 2478-2601. [CrossRef]

40. Mahmudov, K.T.; Kopylovich, M.N.; Guedes da Silva, M.F.C.; Pombeiro, A.J.L. Chalcogen bonding in synthesis, catalysis and design of materials. Dalton Trans. 2017, 46, 10121-10138. [CrossRef]

41. Gleiter, R.; Haberhauer, G.; Werz, D.B.; Rominger, F.; Bleiholder, C. From noncovalent chalcogen-chalcogen interactions to supramolecular aggregates: Experiments and calculations. Chem. Rev. 2018, 118, 2010-2041. [CrossRef] [PubMed]

42. Vogel, L.; Wonner, P.; Huber, S.M. Chalcogen bonding: An overview. Angew. Chem. Int. Ed. 2019, 58, 1880-1891. [CrossRef]

43. Scheiner, S. The pnicogen bond: Its relation to hydrogen, halogen, and other noncovalent bonds. Acc. Chem. Res. 2013, 46, 280-288. [CrossRef]

44. Del Bene, J.E.; Alkorta, I.; Elguero, J. The pnicogen bond in review: Structures, binding energies, bonding properties, and spin-spin coupling constants of complexes stabilized by pnicogen bonds. In Noncovalent Forces; Scheiner, S., Ed.; Springer: Heidelberg, Germany, 2015; pp. 191-264.

45. Brammer, L. Halogen bonding, chalcogen bonding, pnictogen bonding, tetrel bonding: Origins, current status and discussion. Faraday Discuss. 2017, 203, 485-507. [CrossRef]

46. Politzer, P.; Murray, J.S.; Lane, P. $\sigma$-Hole bonding and hydrogen bonding: Competitive interactions. Int. J. Quantum Chem. 2007, 107, 3046-3052. [CrossRef]

47. Zhu, S.; Xing, C.; Xu, W.; Jin, G.; Li, Z. Halogen bonding and hydrogen bonding coexist in driving self-assembly process. Cryst. Growth Des. 2004, 4, 53-56. [CrossRef]

48. Priimagi, A.; Cavallo, G.; Forni, A.; Gorynsztejn-Leben, M.; Kaivola, M.; Metrangolo, P.; Milani, R.; Shishido, A.; Pilati, T.; Resnati, G.; et al. Halogen Bonding versus Hydrogen Bonding in Driving Self-Assembly and Performance of Light-Responsive Supramolecular Polymers. Adv. Funct. Mater. 2012, 22, 2572-2579. [CrossRef]

49. Mukherjee, A.; Tothadi, S.; Desiraju, G.R. Halogen bonds in crystal engineering: Like hydrogen bonds yet different. Acc. Chem. Res. 2014, 47, 2514-2524. [CrossRef] [PubMed]

50. Scheiner, S. Forty years of progress in the study of the hydrogen bond. Struct. Chem. 2019, 30, 1119-1128. [CrossRef]

51. Corradi, E.; Meille, S.V.; Messina, M.T.; Metrangolo, P.; Resnati, G. Halogen Bonding versus Hydrogen Bonding in Driving Self-Assembly Processes. Angew. Chem. Int. Ed. 2000, 39, 1782-1786. [CrossRef]

52. Pascoe, D.J.; Ling, K.B.; Cockroft, S.L. The origin of chalcogen-bonding interactions. J. Am. Chem. Soc. 2017, 139, 15160-15167. [CrossRef]

53. Bora, P.L.; Novák, M.; Novotný, J.; Foroutan-Nejad, C.; Marek, R. Supramolecular covalence in bifurcated chalcogen bonding. Chem. Eur. J. 2017, 23, 7315-7323. [CrossRef]

54. Bhandary, S.; Sirohiwal, A.; Kadu, R.; Kumar, S.; Chopra, D. Dispersion stabilized Se/Te $\cdots \pi$ double chalcogen bonding synthons in in situ cryocrystallized divalent organochalcogen liquids. Cryst. Growth Des. 2018, 18, 3734-3739. [CrossRef]

55. Ams, M.R.; Trapp, N.; Schwab, A.; Milić, J.V.; Diederich, F. Chalcogen Bonding "2S-2N Squares" versus Competing Interactions: Exploring the Recognition Properties of Sulfur. Chem. Eur. J. 2019, 25, 323-333. [CrossRef]

56. Politzer, P.; Murray, J.S.; Concha, M.C. $\sigma$-hole bonding between like atoms; a fallacy of atomic charges. J. Mol. Model. 2008, 14, 659-665. [CrossRef]

57. Cozzolino, A.F.; Vargas-Baca, I.; Mansour, S.; Mahmoudkhani, A.H. The nature of the supramolecular association of 1, 2, 5-chalcogenadiazoles. J. Am. Chem. Soc. 2005, 127, 3184-3190. [CrossRef]

58. De Vleeschouwer, F.; Denayer, M.; Pinter, B.; Geerlings, P.; De Proft, F. Characterization of chalcogen bonding interactions via an in-depth conceptual quantum chemical analysis. J. Comput. Chem. 2018, 39, 557-572. [CrossRef]

59. Bleiholder, C.; Gleiter, R.; Werz, D.B.; Köppel, H. Theoretical Investigations on Heteronuclear Chalcogen- Chalcogen Interactions: On the Nature of Weak Bonds between Chalcogen Centers. Inorg. Chem. 2007, 46, 2249-2260. [CrossRef]

60. Bleiholder, C.; Werz, D.B.; Köppel, H.; Gleiter, R. Theoretical investigations on chalcogen - chalcogen interactions: What makes these nonbonded interactions bonding? J. Am. Chem. Soc. 2006, 128, 2666-2674. [CrossRef] 
61. Politzer, P.; Murray, J.S. An overview of strengths and directionalities of noncovalent interactions: $\sigma$-holes and $\pi$-holes. Crystals 2019, 9, 165. [CrossRef]

62. Politzer, P.; Murray, J.S.; Clark, T.; Resnati, G. The $\sigma$-hole revisited. Phys. Chem. Chem. Phys. 2017, 19, 32166-32178. [CrossRef] [PubMed]

63. Gomila, R.M.; Mooibroek, T.J.; Frontera, A. In A combined theoretical and CSD perspective on $\sigma$-hole interactions with tetrels, pnictogens, chalcogens, halogens, and noble gases. In Hot Topics in Crystal Engineering; Elsevier: Amsterdam, The Netherlands, 2021. [CrossRef]

64. Alkorta, I.; Rozas, I.; Elguero, J. Molecular complexes between silicon derivatives and electron-rich groups. J. Phys. Chem. A 2001, 105, 743-749. [CrossRef]

65. Alkorta, I.; Elguero, J.; Fruchier, A.; Macquarrie, D.J.; Virgili, A. Aminopropylsilanes versus silatranes: An experimental and theoretical study. J. Organomet. Chem. 2001, 625, 148-153. [CrossRef]

66. Grabowski, S.J. Lewis Acid Properties of Tetrel Tetrafluorides-The Coincidence of the $\sigma$-Hole Concept with the QTAIM Approach. Crystals 2017, 7, 43. [CrossRef]

67. Scilabra, P.; Kumar, V.; Ursini, M.; Resnati, G. Close contacts involving germanium and tin in crystal structures: Experimental evidence of tetrel bonds. J. Mol. Model. 2018, 24, 37. [CrossRef] [PubMed]

68. Bauzá, A.; Seth, S.K.; Frontera, A. Tetrel bonding interactions at work: Impact on tin and lead coordination compounds. Coord. Chem. Rev. 2019, 384, 107-125. [CrossRef]

69. Lukevics, E.; Arsenyan, P.; Belyakov, S.; Popelis, J.; Pudova, O. Cycloaddition reactions of nitrile oxides to silyl-and germylsubstituted thiophene-1, 1-dioxides. Organometallics 1999, 18, 3187-3193. [CrossRef]

70. Villaescusa, L.A.; Lightfoot, P.; Morris, R.E. Synthesis and structure of fluoride-containing $\mathrm{GeO}_{2}$ analogues of zeolite double four-ring building units. Chem. Commun. 2002, 2220-2221. [CrossRef] [PubMed]

71. Calogero, S.; Ganis, P.; Peruzzo, V.; Tagliavini, G.; Valle, G. X-ray and Mössbauer studies of tricyclohexyltin (IV) halides. The crystal structures of (cyclo- $\left.\mathrm{C}_{6} \mathrm{H}_{11}\right)_{3} \mathrm{SnX}(\mathrm{X}=\mathrm{F}, \mathrm{Br}$ and I). J. Organomet. Chem. 1981, 220, 11-20. [CrossRef]

72. Wang, J.-Q.; Kuang, D.-Z.; Zhang, F.-X.; Feng, Y.-L.; Xu, Z.-F. CCDC 211279: Experimental Crystal Structure Determination. Wuji Нuaxue Xиebao 2003, 19, 1109.

73. Breugst, M.; Koening, J.J. $\sigma$-Hole Interactions in Catalysis. Eur. J. Org. Chem. 2020, 2020, 5473-5487. [CrossRef]

74. Breugst, M.; von der Heiden, D.; Schmauck, J. Novel Noncovalent Interactions in Catalysis: A Focus on Halogen, Chalcogen, and Anion- $\pi$ Bonding. Synthesis 2017, 49, 3224-3236. [CrossRef]

75. Liao, L.; Zhao, X. Modern Organoselenium Catalysis: Opportunities and Challenges. Synlett 2021, 32, $1262-1268$.

76. Trujillo, C.; Sanchez-Sanz, G.; Alkorta, I.; Elguero, J. Halogen, chalcogen and pnictogen interactions in $\left(\mathrm{XNO}_{2}\right)_{2}$ homodimers (X= F, Cl, Br, I). New J. Chem. 2015, 39, 6791-6802. [CrossRef]

77. Alkorta, I.; Elguero, J.; Grabowski, S.J. Pnicogen and hydrogen bonds: Complexes between $\mathrm{PH}_{3} \mathrm{X}^{+}$and $\mathrm{PH}_{2} \mathrm{X}$ systems. Phys. Chem. Chem. Phys. 2015, 17, 3261-3272. [CrossRef] [PubMed]

78. Esrafili, M.D.; Mohammadian-Sabet, F.; Baneshi, M.M. The dual role of halogen, chalcogen, and pnictogen atoms as Lewis acid and base: Triangular XBr:SHX: $\mathrm{PH}_{2} \mathrm{X}$ complexes $\left(\mathrm{X}=\mathrm{F}, \mathrm{Cl}, \mathrm{Br}, \mathrm{CN}, \mathrm{NC}, \mathrm{OH}, \mathrm{NH}_{2}\right.$, and $\left.\mathrm{OCH}_{3}\right)$. Int. J. Quantum Chem. 2015, 115, 1580-1586. [CrossRef]

79. Adhikari, U.; Scheiner, S. Sensitivity of pnicogen, chalcogen, halogen and H-bonds to angular distortions. Chem. Phys. Lett. 2012, 532, 31-35. [CrossRef]

80. Bauzá, A.; Quinonero, D.; Deyà, P.M.; Frontera, A. Halogen bonding versus chalcogen and pnicogen bonding: A combined Cambridge structural database and theoretical study. CrystEngComm 2013, 15, 3137-3144. [CrossRef]

81. Murray, J.S.; Lane, P.; Politzer, P. A predicted new type of directional noncovalent interaction. Int. J. Quantum Chem. 2007, 107, 2286-2292. [CrossRef]

82. Alkorta, I.; Sánchez-Sanz, G.; Elguero, J. Pnicogen Bonds between $\mathrm{X}-\mathrm{PH}_{3}\left(\mathrm{X}=\mathrm{O}, \mathrm{S}, \mathrm{NH}, \mathrm{CH}_{2}\right)$ and Phosphorus and Nitrogen Bases. J. Phys. Chem. A 2014, 118, 1527-1537. [CrossRef]

83. Shukla, R.; Chopra, D. Characterization of N .. O non-covalent interactions involving $\sigma$-holes: "electrostatics" or "dispersion". Phys. Chem. Chem. Phys. 2016, 18, 29946-29954. [CrossRef]

84. Politzer, P.; Murray, J.S.; Janjić, G.V.; Zarić, S.D. $\sigma$-Hole Interactions of Covalently-Bonded Nitrogen, Phosphorus and Arsenic: A Survey of Crystal Structures. Crystals 2014, 4, 12-31. [CrossRef]

85. Scilabra, P.; Terraneo, G.; Resnati, G. Fluorinated elements of Group 15 as pnictogen bond donor sites. J. Fluor. Chem. 2017, 203, 62-74. [CrossRef]

86. Mokrai, R.; Jaie Barrett, J.; Apperley, D.C.; Benkő, Z.; Heift, D. Tweaking the Charge Transfer: Bonding Analysis of Bismuth(III) Complexes with a Flexidentate Phosphane Ligand. Inorg. Chem. 2020, 59, 8916-8924. [CrossRef] [PubMed]

87. Sarkar, S.; Pavan, M.S.; Guru Row, T.N. Experimental validation of 'pnicogen bonding' in nitrogen by charge density analysis. Phys. Chem. Chem. Phys. 2015, 17, 2330-2334. [CrossRef]

88. Joshi, P.R.; Ramanathan, N.; Sundararajan, K.; Sankaran, K. Evidence for phosphorus bonding in phosphorus trichloride-methanol adduct: A matrix isolation infrared and ab initio computational study. J. Phys. Chem. A 2015, 119, 3440-3451. [CrossRef] [PubMed]

89. Nelyubina, Y.V.; Korlyukov, A.A.; Lyssenko, K.A. Experimental charge density evidence for pnicogen bonding in a crystal of ammonium chloride. ChemPhysChem 2015, 16, 676-681. [CrossRef]

90. Lim, J.Y.C.; Beer, P.D. Sigma-hole interactions in anion recognition. Chem 2018, 4, 731-783. [CrossRef] 
91. Hirai, M.; Cho, J.; Gabbaï, F. Promoting the Hydrosilylation of Benzaldehyde by Using a Dicationic Antimony-Based Lewis Acid: Evidence for the Double Electrophilic Activation of the Carbonyl Substrate. Chem. Eur. J. 2016, 22, 6537-6541. [CrossRef]

92. Qiu, J.; Unruh, D.K.; Cozzolino, A.F. Design, Synthesis, and Structural Characterization of a Bisantimony(III) Compound for Anion Binding and the Density Functional Theory Evaluation of Halide Binding through Antimony Secondary Bonding Interactions. J. Phys. Chem. A 2016, 120, 9257-9269. [CrossRef]

93. Benz, S.; Poblador-Bahamonde, A.I.; Low-Ders, N.; Matile, S. Catalysis with pnictogen, chalcogen, and halogen bonds. Angew. Chem. Int. Ed. 2018, 57, 5408-5412. [CrossRef]

94. Paraja, M.; Gini, A.; Sakai, N.; Matile, S. Pnictogen-Bonding Catalysis: An Interactive Tool to Uncover Unorthodox Mechanisms in Polyether Cascade Cyclizations. Chem. Eur. J. 2020, 26, 15471-15476. [CrossRef]

95. Gini, A.; Paraja, A.; Galmés, B.; Besnard, C.; Poblador-Bahamonde, A.I.; Sakai, N.; Frontera, A.; Matile, S. Pnictogen-bonding catalysis: Brevetoxin-type polyether cyclizations. Chem. Sci. 2020, 11, 7086-7091. [CrossRef] [PubMed]

96. Hao, X.; Li, T.R.; Chen, H.; Gini, A.; Zhang, X.; Rosset, S.; Mazet, C.; Tiefenbacher, K.; Matile, S. Bioinspired Ether Cyclizations within a $\pi$-Basic Capsule Compared to Autocatalysis on $\pi$-Acidic Surfaces and Pnictogen-Bonding Catalysts. Chem. Eur. J. 2021, 27, 12215-12223. [CrossRef]

97. Zhang, J.; Wei, J.; Ding, W.-Y.; Li, S.; Xiang, S.H.; Tan, B. Asymmetric Pnictogen-Bonding Catalysis: Transfer Hydrogenation by a Chiral Antimony(V) Cation/Anion Pair. J. Am. Chem. Soc. 2021, 143, 6382-6387. [CrossRef]

98. Yang, M.; Hirai, M.; Gabbaï, F. Phosphonium-stilbonium and bis-stilbonium cations as pnictogen-bonding catalysts for the transfer hydrogenation of quinolines. Dalton Trans. 2019, 48, 6685-6689. [CrossRef]

99. Humeniuk, H.V.; Gini, A.; Hao, X.; Coelho, F.; Sakai, N.; Matile, S. Pnictogen-Bonding Catalysis and Transport Combined: Polyether Transporters Made In Situ. J. Am. Chem. Soc. 2021, 1, 1588-1593. [CrossRef]

100. Vermeeren, P.; Tiezza, M.D.; van Dongen, M.; Fernández, I.; Bickelhaupt, F.M.; Hamlin, T.A. Lewis Acid-Catalyzed Diels-Alder Reactions: Reactivity Trends across the Periodic Table. Chem. Eur. J. 2021, 27, 10610-10620. [CrossRef]

101. Li, Y.; Meng, L.; Sun, C.; Zeng, Y. Organocatalysis by Halogen, Chalcogen, and Pnictogen Bond Donors in Halide Abstraction Reactions: An Alternative to Hydrogen Bond-Based Catalysis. J. Phys. Chem. A 2020, 124, 3815-3824. [CrossRef] [PubMed]

102. Lu, L.; Lu, Y.; Zhu, Z.; Liu, H. Pnictogen, chalcogen, and halogen bonds in catalytic systems: Theoretical study and detailed comparison. J. Mol. Model. 2020, 26, 16. [CrossRef]

103. Schafer, A.G.; Wieting, J.M.; Fisher, T.J.; Mattson, A.E. Chiral Silanediols in Anion-Binding Catalysis. Angew.Chem. Int. Ed. 2013, 52, 11321-11324. [CrossRef] [PubMed]

104. Zurro, M.; Asmus, S.; Bamberger, J.; Beckendorf, S.; García Mancheño, O. Chiral Triazoles in Anion-Binding Catalysis: New Entry to Enantioselective Reissert-Type Reactions. Chem. Eur. J. 2016, 22, 3785-3793. [CrossRef] [PubMed]

105. Kaneko, S.; Kumatabara, Y.; Shimizu, S.; Maruoka, K.; Shirakawa, S. Hydrogen-bonding catalysis of sulfonium salts. Chem. Commun. 2017, 53, 119-122. [CrossRef]

106. Frisch, M.J.; Trucks, G.W.; Schlegel, H.B.; Scuseria, G.E.; Robb, M.A.; Cheeseman, J.R.; Scalmani, G.; Barone, V.; Petersson, G.A.; Nakatsuji, H.; et al. Gaussian 16, Revision, C.01; Gaussian, Inc.: Wallingford, CT, USA, 2016.

107. Garrett, G.E.; Gibson, G.L.; Straus, R.N.; Seferos, D.S.; Taylor, M.S. Chalcogen bonding in solution: Interactions of benzotelluradiazoles with anionic and uncharged Lewis bases. J. Am. Chem. Soc. 2015, 137, 4126-4133. [CrossRef]

108. Navarro-García, E.; Galmés, B.; Velasco, M.D.; Frontera, A.; Caballero, A. Anion Recognition by Neutral Chalcogen Bonding Receptors: Experimental and Theoretical Investigations. Chem. Eur. J. 2020, 26, 4706-4713. [CrossRef] [PubMed]

109. Cozzolino, A.F.; Elder, P.J.W.; Vargas-Vaca, I. A survey of tellurium-centered secondary-bonding supramolecular synthons. Coord. Chem. Rev. 2011, 255, 1426-1438. [CrossRef]

110. Scheiner, S. Detailed comparison of the pnicogen bond with chalcogen, halogen, and hydrogen bonds. Int. J. Quantum Chem. 2013, 113, 1609-1620. [CrossRef]

111. Nziko, V.P.N.; Scheiner, S. Chalcogen Bonding between Tetravalent $\mathrm{SF}_{4}$ and Amines. J. Phys. Chem. A 2014, 118, 10849-10856. [CrossRef]

112. Benz, S.; Mareda, J.; Besnard, C.; Sakai, N.; Matile, S. Catalysis with chalcogen bonds: Neutral benzodiselenazole scaffolds with high-precision selenium donors of variable strength. Chem. Sci. 2017, 8, 8164-8169. [CrossRef]

113. Wang, W.; Zhu, S.; Liu, Z.; Zhao, L.; Zhang, J.; Hao, J.; Wang, Y. Chalcogen-Chalcogen Bonding Catalysis Enables Assembly of Discrete Molecules. J. Am. Chem. Soc. 2019, 141, 9175-9179. [CrossRef]

114. Wang, W.; Zhu, H.; Feng, L.; Yu, Q.; Hao, J.; Zhu, R.; Wang, Y. Dual Chalcogen-Chalcogen Bonding Catalysis. J. Am. Chem. Soc. 2020, 142, 3117-3124. [CrossRef]

115. Bao, L.; Kong, X.; Wang, Y. Noncovalent Chalcogen-Bonding Catalysis Using ppm-Level Catalyst Loading to Achieve Cyanosilylation of Ketones. Asian J. Org. Chem. 2020, 9, 757-760. [CrossRef]

116. Wonner, P.; Dreger, A.; Vogel, L.; Engelage, E.; Huber, S.M. Chalcogen Bonding Catalysis of a Nitro-Michael Reaction. Angew. Chem. Int. Ed. 2019, 58, 16923-16927. [CrossRef]

117. Weiss, R.; Aubert, E.; Pale, P.; Mamane, V. Chalcogen-Bonding Catalysis with Telluronium Cations. Angew. Chem. Int. Ed. 2021, 60, 19281-19286. [CrossRef]

118. He, X.; Wang, X.; Steve Tse, Y.L.; Ke, Z.; Yeung, Y.Y. Bis-selenonium Cations as Bidentate Chalcogen Bond Donors in Catalysis. ACS Catal. 2021, 11, 12632-12642. [CrossRef]

119. Zhou, B.; Gabbai, F.P. Lewis Acidic Telluronium Cations: Enhanced Chalcogen-Bond Donor Properties and Application to Transfer Hydrogenation Catalysis. Organometallics 2021, 40, 2371-2374. [CrossRef] 
120. Tarannam, N.; Voelkel, M.H.; Huber, H.; Matile, S.; Kozuch, S. Chalcogen vs Halogen Bonding Catalysis in a Water-BridgeCocatalyzed Nitro-Michael Reaction. J. Org. Chem. 2021. [CrossRef] [PubMed]

121. Benyu, Z.; Gabbai, F.P. Anion Chelation via Double Chalcogen Bonding: The Case of a Bis-telluronium Dication and Its Application in Electrophilic Catalysis via Metal-Chloride Bond Activation. J. Am. Chem. Soc. 2021, 143, 8625-8630.

122. Xiangjin, K.; Pan-Pan, Z.; Yao, W. Chalcogen $\cdots \pi$ Bonding Catalysis. Angew. Chem. Int. Ed. 2021, 60, 9395-9400.

123. Steinke, T.; Wonner, P.; Engelape, E.; Huber, H.; Matile, S. Catalytic Activation of a Carbon-Chloride Bond by Dicationic Tellurium-Based Chalcogen Bond Donors. Synthesis 2021, 53, 2043-2050.

124. Weiss, R.; Aubert, E.; Peluso, P.; Cossu, S.; Pale, P.; Mamane, V. Chiral chalcogen bond donors based on the 4,4'-bipyridine scaffold. Molecules 2019, 24, 4484. [CrossRef]

125. Wonner, P.; Steinke, T.; Vogel, L.; Huber, H.; Matile, S. Carbonyl Activation by Selenium- and Tellurium-Based Chalcogen Bonding in a Michael Addition Reaction. Chem. Eur. J. 2020, 26, 1258-1262. [CrossRef]

126. Wonner, P.; Steinke, T.; Huber, H.; Matile, S. Activation of Quinolines by Cationic Chalcogen Bond Donors. Synlett 2019, 30, 1673-1678. [CrossRef] 